\title{
Association between TP53 genetic polymorphisms and the methylation and expression of miR-34a, 34b/c in colorectal cancer tissues
}

\author{
HAK HOON JUN ${ }^{1 *}$, KYUBUM KWACK $^{2 *}$, KEUN HEE LEE $^{1}$, JUNG OH KIM ${ }^{2}$, HAN SUNG PARK ${ }^{2}$, \\ CHANG SOO RYU ${ }^{2}$, JEONG YONG LEE ${ }^{2}$, DAEUN KO ${ }^{3}$, JONG WOO KIM ${ }^{1}$ and NAM KEUN KIM ${ }^{2}$ \\ ${ }^{1}$ Department of Surgery, CHA Bundang Medical Center, School of Medicine, CHA University, Seongnam 13496; \\ ${ }^{2}$ Department of Biomedical Science, College of Life Science, CHA University, Seongnam 13488; \\ ${ }^{3}$ Department of Anesthesiology and Pain Medicine, CHA Bundang Medical Center, CHA University, \\ Seongnam 13496, Republic of Korea
}

Received September 3, 2018; Accepted January 31, 2019

DOI: $10.3892 / 01.2019 .10092$

\begin{abstract}
Colorectal cancer (CRC) is one of the most common types of cancers, as evidenced by the $>1.2$ million patient diagnoses and 600,000 mortalities globally each year. Recently, the microRNA (miR/miRNA)-34 miRNA precursor family was revealed to participate in the tumor protein (TP)-53 pathway, which is frequently involved in CRC. Furthermore, the expression of miR-34 is reportedly regulated by DNA methylation. Accordingly, the present study investigated the correlation between the methylation status of miR-34 miRNAs and miR-34 expression in paired CRC tumor and normal tissues. The methylation status of miR-34a and miR-34b/c was determined using the MethyLight assay, and the expression of $\mathrm{miR}-34 \mathrm{a}$ and $\mathrm{miR}-34 \mathrm{~b} / \mathrm{c}$ in the same paired tissues was analyzed by reverse transcription-quantitative polymerase chain reaction. The results revealed significantly elevated miR-34a $(\mathrm{P}=0.012)$ and miR-34b/c $(\mathrm{P}<0.0001)$ methylation levels in tumor tissues when compared with normal tissues, whereas only the expression of miR-34b/c differed $(\mathrm{P}=0.005)$ between the paired tissues. In addition, an association between TP53 haplotypes and miR-34 family expression levels was
\end{abstract}

Correspondence to: Professor Nam Keun Kim, Department of Biomedical Science, College of Life Science, CHA University, 335 Pangyo-ro, Seongnam 13488, Republic of Korea

E-mail:nkkim@cha.ac.kr

Dr Jong Woo Kim, Department of Surgery, CHA Bundang Medical Center, School of Medicine, CHA University, 59 Yatap-ro, Bundang-gu, Seongnam 13496, Republic of Korea

E-mail: jwkim@cha.ac.kr

${ }^{*}$ Contributed equally

Key words: tumor protein 53, microRNA-34a, microRNA-34b, microRNA-34c, single nucleotide polymorphism, DNA methylation, expression observed. The miR-34a methylation levels in the TP53 PIN

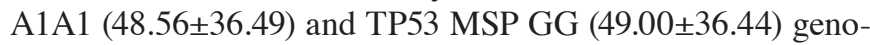
types were increased in the tumor tissues when compared with normal tissues. In conclusion, it was determined that miR-34 promoter methylation and TP53 polymorphisms may be associated with $\mathrm{CRC}$ pathogenesis.

\section{Introduction}

Colorectal cancer (CRC) is one of the most common cancers, affecting more than 1.2 million patients and resulting in 600,000 deaths annually $(1,2)$. According to the National Cancer Information Center of Korea, CRC has the third highest incidence rate in both males and females, and the second highest mortality rate in females (3). Established CRC risk factors include exposure to processed meats and alcohol, smoking, and gamma radiation; however, recent studies have likewise investigated the effects of the microRNA (miR/miRNA)-34 miRNA precursor family $(1,2)$.

MicroRNAs (miRNAs, miRs) are small, 22-24 nucleotide non-coding RNAs that negatively regulate the translation of messenger RNA to protein via base pairing to a partially complementary sequence in the open reading frames and 3'-untranslated regions (3'-UTR) (4,5). Further, miRNAs are encoded across the entire genome, including exonic, intronic, and intergenic regions. However, almost all miRNAs are found in intronic regions (6). The RNA polymerases RNase II or III transcribe miRNAs as long primary transcripts (pri-miRNAs), which are then processed into stem-loop structure miRNA precursor molecules (pre-miRNAs) in the nucleus by a nuclear complex consisting of Drosha, a member of the ribonuclease III family (RNase III), and its cofactors (DGCR8) (7,8). The pre-miRNAs are exported to the cytoplasm by exportin-5 (XPO5) and processed into mature, 18-25 nucleotide (nt) miRNAs following cleavage of the double-stranded portion of the hairpin by the RNase III enzyme Dicer $(9,10)$. Altered miR expression resulting from deregulation occurs in several human diseases including cancer. As well, miRs act as either tumor suppressor genes 
or oncogenes, resulting in the dissemination of cancer (11-13). The deregulation of $\mathrm{miR}$ via the epigenetic silencing of $\mathrm{miR}$ expression is likewise associated with $\mathrm{CpG}$ island methylation and repressive histone modifications (11).

The miRNA-34 family, comprised of miR-34a, miR-34b, and miR-34c, is part of the p53 network, which induces the expression of miR-34 miRNAs in response to DNA damage or oncogenic stress (14-16). Located on chromosome 1p36, miR-34a is associated with glioma, neuroblastoma, pancreatic cancer, and chronic myelogenous leukemia (17-20), and is the key regulator of cell cycle progression (E2F3) and apoptosis (BCL2) $(14,15,20)$. Reduced miR-34a expression is frequently observed in pancreatic tumors and neuroblastomas $(18,21)$. Located on chromosome 11q23, miR-34b and miR-34c are co-transcribed from one transcription unit (22). Reduced $\mathrm{miR}-34 \mathrm{~b} / \mathrm{c}$ expression is seen in non-small cell lung cancer (20). The methylation of miR-34b/c CpG sites has been found in CRC (23) and oral squamous cell carcinoma (24) as well as malignant melanoma, in which $\mathrm{miR}-34 \mathrm{~b} / \mathrm{c} \mathrm{CpG}$ site methylation is likewise correlated with metastatic potential (25). The cancer-related downregulation of members of the miR-34 family indicates that these miRs function as tumor-suppressor genes, suggesting a potential prognostic marker role (26).

Several mechanisms, including gene amplification, deletion, epigenetic alterations, and single-nucleotide substitutions, have been implicated as potential regulators of $\mathrm{miR}$ expression; however, to date, no studies have actually demonstrated a precise regulatory role for miR expression $(26,27)$. Although single nucleotide polymorphisms (SNPs) in miRs are not considered functionally important, nucleotide variations in primary (pri)- or precursor (pre)-miRs may affect miR processing and result in modified miR expression (28). Recently, studies reported that rs4938723, a potentially functional SNP in the promoter region of pri-miR-34b/c, may contribute to susceptibility to hepatocellular carcinoma (29), CRC (30), endometrial cancer (31), and decreased breast cancer survival (32). However, reports on the relationship between SNPs in the miR-34b/c promoter and the subsequent risk and prognostic significance in CRC patients are limited.

Mutations in p53 reportedly initiate or participate in early events in several diverse cancers types. Prior reports likewise indicate that the tumorigenicity is related to the deregulation of p53-mediated transcription (28). Of the variations in the TP53 gene, Arg72Pro is the most widely investigated. The 72Arg allele induces apoptosis more efficiently than the 72Pro allele (32). Prior reports have indicated that Pro homozygosity in TP53Arg72Pro is a potential risk factor for lung, esophageal, stomach, breast, nasopharynx, urothelium, and prostate cancers $(33,34)$. However, the results of a meta-analysis of CRC, performed to estimate the effect of the TP53Arg72Pro polymorphism on CRC risk, failed to identify a significant association (35). Conversely, we detected a negative relationship between the TP53Arg72Pro polymorphism and CRC risk in the Korean population. Transcriptional silencing of $\mathrm{CpG}$ methylation represents an important mechanism for the inactivation of key tumor suppressor genes $(25,36)$, and approximately $60 \%$ of $\mathrm{CpG}$ islands are located in promoter regions. However, only $\mathrm{CpG}$ islands located in promoter regions exhibit methylation of cytosine at position 5 and the inactivation of surrounding chromatin via the recruitment of histone deacetylases following proteins binding to methylated CpG residues (37). Therefore, the aim of this study has investigated the differences in the degree of methylation according to SNPs in the DNA promoter region (Fig. 1) and confirmed the changes in the expression pattern of the miR-34 family according to the gene mutation of p53.

\section{Materials and methods}

Tissue samples and genomic DNA isolation. Paired tumor and normal tissues were retrospectively selected from 104 CRC patients treated at the CHA Bundang Medical Center (Seongnam, Korea) between March 2010 and March 2012. Genomic DNA (gDNA) isolation was performed according to an established protocol (38). Briefly, $50 \mu \mathrm{l}$ of solution 1 (420 $\mu \mathrm{l}$ STE buffer and 10\% SDS) was added to the tissues followed by the addition of $30 \mu \mathrm{l}$ proteinase $\mathrm{K}$ and overnight incubation at $50^{\circ} \mathrm{C}$. After incubation, $500 \mu \mathrm{l}$ of solution 2 (phenol:chloroform:isoamyl alcohol=25:24:1) was added to the tissue samples and the supernatants were collected following centrifugation. Next, $500 \mu \mathrm{l}$ of solution 3 (chloroform:isoamyl alcohol=24:1) was added, the supernatants were collected after centrifugation, and $25 \mu \mathrm{l} 3 \mathrm{M}$ sodium acetate and $900 \mu \mathrm{l}$ $100 \% \mathrm{EtOH}$ were added. The samples were centrifuged again, and the resulting supernatants were quenched on ice for $1 \mathrm{~h}$. The resulting gDNA samples were dissolved in the rehydration buffer. The present study was approved by the Institutional Review Board of CHA Bundang Medical Center; IRB no. 2009-08-077-010) and written informed consent was provided by all patients.

Genetic analysis. Three TP53 single nucleotide polymorphisms (SNPs), TP53 codon 72G>C (rs1042522, Arg >Pro, exon 4), TP53 MSPI A>G (rs1625895, intron 6), and TP53 PIN (rs17878362, intron 6), and one miR-34b/c SNP, miR-34bc $\mathrm{T}>\mathrm{C}$ (rs4938723, promoter) were selected from the human genome SNP database (dbSNP, www.ncbi.nlm.nih.gov/snp). The genotypes were determined using a polymerase chain reaction (PCR)-restriction fragment length polymorphism assay. The PCR primers for the TP53 codon $72 \mathrm{G}>\mathrm{C}$ polymorphism were forward 5'-TTGCCGTCCCAAGCAATG GATGA-3' and reverse 5'-TCTGGGAAGGGACAGAAG ATGAC-3'. The PCR conditions included an initial $5 \mathrm{~min}$ of denaturation at $94^{\circ} \mathrm{C}$ followed by 35 cycles of denaturing at $94^{\circ} \mathrm{C}$ for $30 \mathrm{sec}$, annealing at $56^{\circ} \mathrm{C}$ for $30 \mathrm{sec}$, and extension at $72^{\circ} \mathrm{C}$ for $30 \mathrm{sec}$ followed by a final extension at $72^{\circ} \mathrm{C}$ for $5 \mathrm{~min}$. The PCR products were cut using the $B s t \mathrm{UI}$ restriction enzyme (New England Biolabs, Beverly, MA, USA) at $60^{\circ} \mathrm{C}$ for $16 \mathrm{~h}$.

The PCR primers for the TP53 MSPI A>G polymorphism were forward 5'-ATAGTGTGGTGGTGCCCTAT-3' and reverse 5'-CCTTAGCCTCTGTAAGCTTCA-3', and the primers for the TP53 PIN polymorphism were forward: 5'-GACTGACTTTCTGCTCTTGTCTT-3' and reverse 5'-ATC GTCCGG-3'. The PCR conditions included an initial 5 min of denaturation at $94^{\circ} \mathrm{C}$ followed by 35 cycles of denaturing at $94^{\circ} \mathrm{C}$ for $30 \mathrm{sec}$, annealing at $60^{\circ} \mathrm{C}$ for $30 \mathrm{sec}$, and extension at $72^{\circ} \mathrm{C}$ for $30 \mathrm{sec}$ followed by a final extension at $72^{\circ} \mathrm{C}$ for $5 \mathrm{~min}$. The PCR products were cut using the $M S P I$ restriction enzyme (New England Biolabs) at $37^{\circ} \mathrm{C}$ for $16 \mathrm{~h}$. 

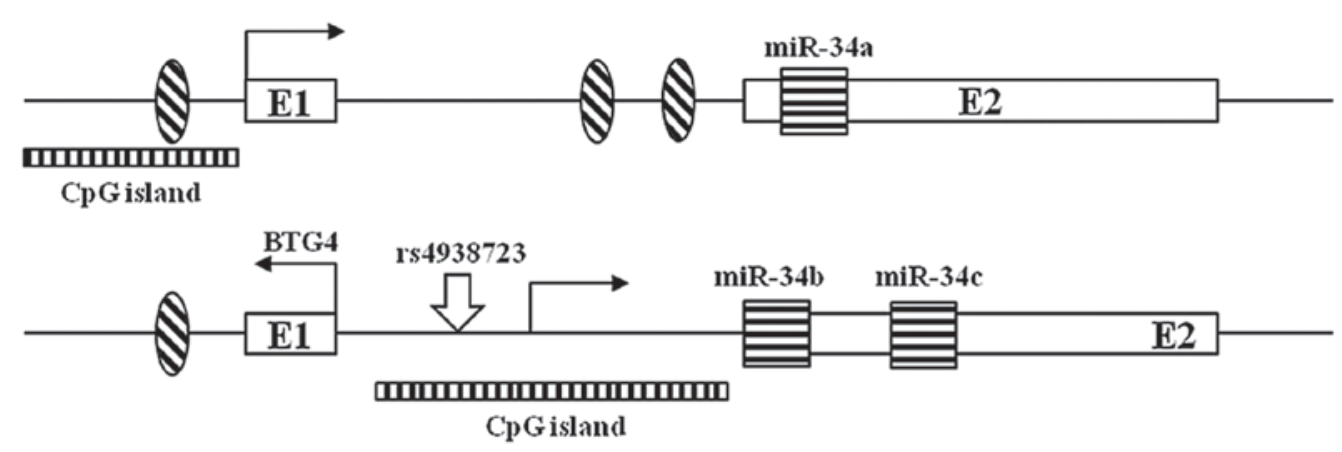

Figure 1. Structure of the miR-34a and miR-34b/c genes. The hatched oval shapes indicate p53-binding sites and the white boxes represent exons. Black striped boxes indicate miR hairpins. $\mathrm{CpG}$ islands are indicated as the long black striped rectangles. miR, microRNA.

The PCR primers for the miR-34b/c T>C polymorphism were forward 5'-CCTCTGGGAACCTTCTTTGACCAAT-3' and reverse 5'-TGAGATCAAGGCCATACCATTCAAGA-3'. The PCR conditions included an initial 5 min of denaturation at $94^{\circ} \mathrm{C}$ was followed by 35 cycles of denaturing at $94^{\circ} \mathrm{C}$ for $30 \mathrm{sec}$, annealing at $55^{\circ} \mathrm{C}$ for $30 \mathrm{sec}$, and extension at $72^{\circ} \mathrm{C}$ for $30 \mathrm{sec}$ followed by a final extension at $72^{\circ} \mathrm{C}$ for $5 \mathrm{~min}$. The PCR products were cut using the Tsp509I restriction enzyme (New England Biolabs) at $65^{\circ} \mathrm{C}$ for $16 \mathrm{~h}$.

All of the resulting PCR products were analyzed by gel electrophoresis. In this study, the designated A1 and A2 alleles for the TP53 PIN polymorphism indicated a 16-base pair (bp) deletion and insertion in intron 6 , respectively.

gDNA bisulfite modification and methylation analysis. The DNA was treated with bisulfite using an EZ DNA methylation kit (Zymo Research, Irvine, CA, USA). The modified DNA was then eluted in a final volume of $10 \mu \mathrm{l}$ and $1 \mu \mathrm{l}$ was used for the real-time methylation PCR (MethyLight). Typically, methylation-specific PCR (MSP) is used to measure DNA methylation, but we opted to use the semi-Quantitative MethyLight technology (39). In the MethyLight technology, the discrimination is made during the PCR amplification step using primers and probes that specifically anneal to either the converted methylated or converted unmethylated sequence. Real-time PCR was performed in triplicate to confirm the results, and the average value was used. The EpiTect ${ }^{\circledR}$ PCR control DNA set was also used (Qiagen, Valencia, CA, USA). The resulting data were analyzed using the Cmeth method (EpiTect ${ }^{\circledR}$ MethyLight PCR Handbook; Qiagen) (40).

RNA extraction and reverse transcriptase reaction. Total RNA was extracted from each tumor and normal tissue sample using the TRIzol ${ }^{\circledR}$ reagent (Invitrogen; Thermo Fisher Scientific, Inc., Waltham, MA, USA) and treated with RNase-free DNase (Promega, Madison, WI, USA). The concentration of the RNA was measured using a spectrophotometer and the samples were stored at $-80^{\circ} \mathrm{C}$ until analysis. Reverse transcription (RT) of the total RNA was performed using an Invitrogen RT kit according to the manufacturer's instructions.

$R T$-quantitative polymerase chain reaction $(R T-q P C R)$ analysis. The expression of miR was measured by $\mathrm{qPCR}$ using the EvaGreen ${ }^{\circledR}$ Master Mix, primers for each gene, and the Rotor-Gene RG-3000 thermal cycler (Corbett Research).
The primer sequences were as follows (forward and reverse): ACTB (213 bp) 5'TGACATTAAGGAGAAGCTGTGCTAC3' and 5'GAGTTGAAGGTAGTTTCGTGGATG3'; miR-34a (128 bp) 5'CGTCACCTCTTAGGCTTGGA3' and 5'CAT TGGTGTCGTTGTGCTCT3'; and miR-34b/c (84 bp) 5'-GTG CTCGGTTTGTAGGCAGT3' and 5'-GTGCCTTGTTTTGAT GGCAG3' $(7,41)$. The expression results were calculated using the $-\Delta \Delta \mathrm{Cq}$ method and expressed graphically using ACTB ( $\beta$-actin) as the reference gene (42). The experiments were performed in triplicate and the average values were used.

Statistical analysis. Statistical analysis was performed using GraphPad Prism 4.0 (GraphPad Software, Inc., La Jolla, CA, USA) and MedCalc version 12.1.4 (MedCalc Software bvba, Ostend, Belgium). The genotype and allele frequencies were calculated to investigate deviations from Hardy-Weinberg equilibrium. The expression pattern of the miRNA identified in CRC tissues was analyzed using Student's t-test and one-way analysis of variance with Student-Newman-Keuls post hoc test. The allele combinations were estimated with SNPAlyze version 5.1 (Dynacom Co., Ltd., Nakase, Japan) and HapStat version 3.0 (dlin.web.unc.edu/). The results are presented as the mean \pm standard deviation. $\mathrm{P}<0.05$ was considered to indicate a statistically significant difference.

\section{Results}

Of the 104 CRC patients, 54 were colon cancer patients and 50 were rectal cancer patients. The mean age was 64 years. Other clinical characteristics including sex, TNM stage, tumor location, and tumor size are summarized in Table I. The relationship between miR-34 methylation level and clinical characteristics was further evaluated. A significant association was found between miR-34a methylation level and age in tumor tissues ( $>64$ vs. $\leq 64$ years; $\mathrm{P}=0.035$ ). However, no significant association was detected between miR-34 methylation level and sex, location of the primary tumor, TNM stage, tumor size, or BMI (Table I).

The data analysis was performed using the Cmeth method and the EpiTect ${ }^{\circledR}$ PCR control DNA set (Qiagen). The correlation of methylation status and miR-34 expression levels between normal and tumor tissue are shown in Fig. 2. The tumor tissue exhibited higher miR-34a (normal tissue: $35.93 \pm 3.53$ vs. tumor tissue: $48.99 \pm 3.57 ; \mathrm{P}=0.012$ ) and $\mathrm{miR}-34 \mathrm{~b} / \mathrm{c}$ (normal tissue: $13.08 \pm 1.94$ vs. tumor tissue: $55.63 \pm 3.35$; $\mathrm{P}<0.0001)$ 
Table I. Associations between miR-34 methylation level and clinical characteristics of colorectal cancer patients.

\begin{tabular}{|c|c|c|c|c|c|c|c|c|c|}
\hline \multirow[b]{2}{*}{ Characteristic } & \multirow[b]{2}{*}{$\begin{array}{c}\text { Total } n \\
(\mathrm{n}=104), \mathrm{n}(\%)\end{array}$} & \multicolumn{4}{|c|}{ Normal tissue } & \multicolumn{4}{|c|}{ Tumor tissue } \\
\hline & & miR-34a & P-value ${ }^{a}$ & $\mathrm{miR}-34 \mathrm{~b} / \mathrm{c}$ & P-value & miR-34a & P-value & $\mathrm{miR}-34 \mathrm{~b} / \mathrm{c}$ & P-value \\
\hline \multicolumn{10}{|l|}{ Sex } \\
\hline Male & $61(58.7)$ & $37.07 \pm 37.42$ & 0.851 & $12.40 \pm 19.17$ & 0.628 & $46.46 \pm 36.30$ & 0.554 & $57.25 \pm 31.54$ & 0.407 \\
\hline Female & $43(41.3)$ & $35.71 \pm 35.18$ & & $14.31 \pm 20.11$ & & $50.77 \pm 36.70$ & & $51.71 \pm 34.73$ & \\
\hline \multicolumn{10}{|l|}{ Age, years } \\
\hline$>64$ & $55(52.9)$ & $36.76 \pm 34.93$ & 0.897 & $11.73 \pm 18.55$ & 0.381 & $56.93 \pm 35.08$ & $0.035^{\mathrm{c}}$ & $54.60 \pm 35.96$ & 0.864 \\
\hline$\leq 64$ & $49(47.1)$ & $35.84 \pm 37.15$ & & $15.12 \pm 20.63$ & & $41.92 \pm 36.45$ & & $53.47 \pm 31.27$ & \\
\hline \multicolumn{10}{|l|}{ TNM stage } \\
\hline 1 & $5 \quad(4.8)$ & $34.82 \pm 41.51$ & $0.967^{\mathrm{b}}$ & $12.05 \pm 15.42$ & $0.178^{\mathrm{b}}$ & $63.02 \pm 42.83$ & $0.728^{\mathrm{b}}$ & $64.40 \pm 34.64$ & $0.073^{\mathrm{b}}$ \\
\hline 2 & $23(22.1)$ & $33.17 \pm 34.05$ & & $21.17 \pm 25.92$ & & $46.07 \pm 37.16$ & & $59.42 \pm 36.58$ & \\
\hline 3 & $66(63.5)$ & $37.06 \pm 36.15$ & & $11.89 \pm 18.19$ & & $47.88 \pm 36.92$ & & $55.16 \pm 31.65$ & \\
\hline 4 & $10(9.6)$ & $38.95 \pm 41.42$ & & $7.43 \pm 8.54$ & & $56.05 \pm 30.79$ & & $28.70 \pm 29.55$ & \\
\hline \multicolumn{10}{|l|}{ Tumor site } \\
\hline Colon & $54(51.9)$ & $35.08 \pm 34.57$ & 0.726 & $16.60 \pm 22.83$ & 0.097 & $51.15 \pm 37.46$ & 0.532 & $53.57 \pm 33.07$ & 0.892 \\
\hline Rectum & $50(48.1)$ & $37.57 \pm 37.69$ & & $10.20 \pm 15.06$ & & $46.66 \pm 35.49$ & & $54.46 \pm 34.09$ & \\
\hline \multicolumn{10}{|l|}{ Tumor size, cm } \\
\hline$<5$ & $38(36.5)$ & $42.41 \pm 37.19$ & 0.188 & $13.56 \pm 19.01$ & 0.989 & $54.69 \pm 36.71$ & 0.227 & $51.61 \pm 35.91$ & 0.582 \\
\hline$\geq 5$ & $66(63.5)$ & $32.74 \pm 35.02$ & & $13.50 \pm 20.17$ & & $45.70 \pm 36.12$ & & $55.38 \pm 32.07$ & \\
\hline \multicolumn{10}{|l|}{$\mathrm{BMI}, \mathrm{kg} / \mathrm{m}^{2}$} \\
\hline$\leq 25$ & $80(76.9)$ & $38.77 \pm 36.25$ & 0.198 & $13.34 \pm 19.94$ & 0.863 & $49.24 \pm 35.92$ & 0.899 & $53.15 \pm 33.62$ & 0.638 \\
\hline$>25$ & $24(23.1)$ & $27.96 \pm 34.35$ & & $14.14 \pm 19.08$ & & $48.16 \pm 38.82$ & & $56.84 \pm 33.22$ & \\
\hline
\end{tabular}

${ }^{\mathrm{a}} \mathrm{P}$-value calculated by paired t-test; ${ }^{\mathrm{b}} \mathrm{P}$-value calculated by one-way analysis of variance test; ${ }^{\mathrm{c}} \mathrm{P}<0.05$. miR, microRNA.
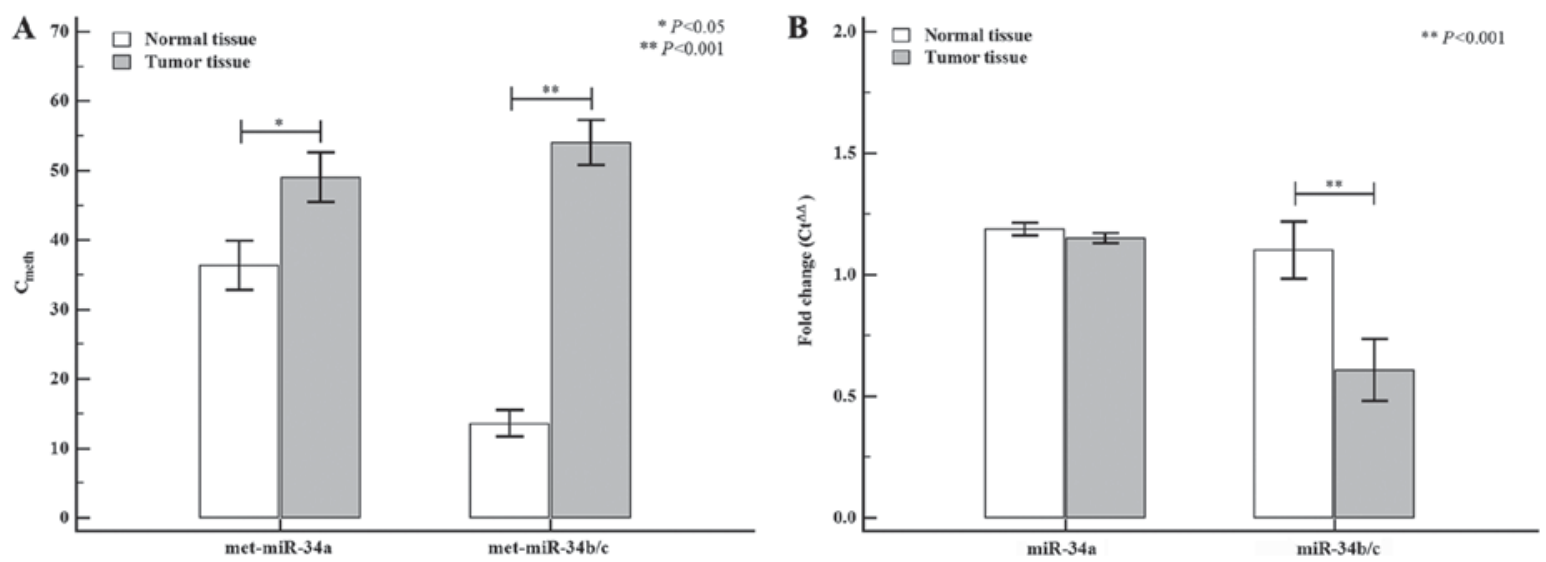

Figure 2. Methylation and expression levels of the miR-34 family between normal and tumor tissues. (A) The methylation status $\left(\mathrm{C}_{\mathrm{meth}}\right)$ of miR-34 miRNAs The miR-34a methylation status was significantly different in normal and tumor tissues $(\mathrm{P}=0.012)$. In addition, the methylation of miR-34b/c was lower in normal tissues (13.08 \pm 1.94 ) than in tumor tissues (55.63 \pm 3.35 ). (B) Of the different miR-34 family, only miR-34b/c exhibited significantly different expression between normal and tumor tissues $(\mathrm{P}=0.005)$. ${ }^{*} \mathrm{P}<0.05$ and ${ }^{* *} \mathrm{P}<0.01$, as indicated. miR/miRNA, microRNA; met, methylated.

methylation levels than the normal tissue, whereas differences in miR-34 miRNA expression levels between normal and tumor tissues were only detected for $\mathrm{miR}-34 \mathrm{~b} / \mathrm{c}$ (normal tissue: $1.10 \pm 1.19$ vs. tumor tissue: $0.60 \pm 1.56 ; \mathrm{P}=0.005)$. The correlation of the methylation status of miR-34 miRNAs between colon and rectal tumors is shown in Fig. 3. When the tumor tissue was stratified by tumor location (colon or rectum), the methylation level of miR-34a was higher in colon tumors (normal tissue: $35.66 \pm 4.78$ vs. tumor tissue: $51.30 \pm 5.12$; $\mathrm{P}=0.041$ ) than in rectal tumors (normal tissue: $35.39 \pm 5.32$ vs. tumor tissue: $45.24 \pm 5.10 ; \mathrm{P}=0.141$ ), but the differences were not statistically significant. However, the methylation level of miR-34b/c in colon tumors was significantly higher (normal tissue: $16.48 \pm 3.12$ vs. tumor tissue: $55.34 \pm 4.63$; 
Table II. TP53 and miR-34b/c genotype frequencies and miR-34 methylation status in normal and tumor tissues.

\begin{tabular}{|c|c|c|c|c|c|c|c|}
\hline \multirow[b]{2}{*}{ Genotypes } & \multirow[b]{2}{*}{ CRC $(\mathrm{n}=104), \mathrm{n}(\%)$} & \multicolumn{3}{|c|}{$\operatorname{miR}-34 a$} & \multicolumn{3}{|c|}{$\mathrm{miR}-34 \mathrm{~b} / \mathrm{c}$} \\
\hline & & Normal tissue & Tumor tissue & P-value ${ }^{b}$ & Normal tissue & Tumor tissue & P-value ${ }^{b}$ \\
\hline \multicolumn{8}{|c|}{ TP53 72 codon } \\
\hline GG & $46(44.2)$ & $35.40 \pm 34.22$ & $46.96 \pm 34.69$ & 0.111 & $14.44 \pm 20.76$ & $55.14 \pm 35.65$ & $<0.001^{\mathrm{e}}$ \\
\hline GC & $42(40.4)$ & $31.58 \pm 36.90$ & $43.82 \pm 38.06$ & 0.138 & $14.55 \pm 21.09$ & $54.60 \pm 32.81$ & $<0.001^{\mathrm{e}}$ \\
\hline $\mathrm{CC}$ & $16(15.4)$ & $51.11 \pm 36.62$ & $68.38 \pm 32.43$ & 0.168 & $8.19 \pm 10.44$ & $49.15 \pm 29.60$ & $<0.001^{\mathrm{e}}$ \\
\hline P-value ${ }^{a}$ & & 0.177 & 0.062 & & 0.502 & 0.820 & \\
\hline \multicolumn{8}{|l|}{ TP53 PIN } \\
\hline A1A1 & $96(92.3)$ & $35.93 \pm 36.00$ & $48.56 \pm 36.49$ & $0.017^{\mathrm{c}}$ & $13.39 \pm 20.01$ & $53.60 \pm 33.89$ & $<0.001^{\mathrm{e}}$ \\
\hline A1A2 & $7 \quad(6.7)$ & $39.83 \pm 40.48$ & $51.91 \pm 40.01$ & 0.585 & $16.42 \pm 16.60$ & $55.58 \pm 29.02$ & $0.009^{\mathrm{d}}$ \\
\hline $\mathrm{A} 2 \mathrm{~A} 2$ & $1 \quad(1.0)$ & 44.14 & 69.38 & & 6.00 & 81.30 & \\
\hline P-value ${ }^{a}$ & & 0.941 & 0.833 & & 0.862 & 0.710 & \\
\hline \multicolumn{8}{|l|}{ TP53 MSP } \\
\hline GG & $95(91.3)$ & $35.60 \pm 36.05$ & $49.00 \pm 36.44$ & $0.012^{\mathrm{c}}$ & $13.32 \pm 20.10$ & $53.51 \pm 34.05$ & $<0.001^{\mathrm{e}}$ \\
\hline $\mathrm{AG}$ & $8 \quad(7.7)$ & $43.24 \pm 38.70$ & $46.32 \pm 40.27$ & 0.878 & $16.86 \pm 15.42$ & $56.41 \pm 26.97$ & $0.003^{\mathrm{d}}$ \\
\hline $\mathrm{AA}$ & $1 \quad(1.0)$ & 44.14 & 69.38 & & $6.00 \pm 0.00$ & 81.30 & \\
\hline P-value & & 0.829 & 0.839 & & 0.827 & 0.698 & \\
\hline \multicolumn{8}{|l|}{$m i R-34 b / c$} \\
\hline TT & $55(52.9)$ & $41.55 \pm 38.35$ & $46.73 \pm 36.61$ & 0.471 & $14.50 \pm 19.90$ & $59.64 \pm 31.19$ & $<0.001^{\mathrm{e}}$ \\
\hline $\mathrm{TC}$ & $41(39.4)$ & $32.15 \pm 34.12$ & $51.61 \pm 35.64$ & $0.014^{\mathrm{c}}$ & $13.44 \pm 20.57$ & $45.51 \pm 35.27$ & $<0.001^{\mathrm{e}}$ \\
\hline $\mathrm{CC}$ & $8 \quad(7.7)$ & $21.11 \pm 20.91$ & $51.14 \pm 42.82$ & 0.096 & $7.26 \pm 12.72$ & $58.76 \pm 33.27$ & $0.001^{\mathrm{e}}$ \\
\hline P-value ${ }^{a}$ & & 0.208 & 0.801 & & 0.627 & 0.112 & \\
\hline
\end{tabular}

${ }^{a} \mathrm{P}$-value calculated by one-way analysis of variance test; ${ }^{\mathrm{b}} \mathrm{P}$-value calculated by paired t-test; ${ }^{\mathrm{C}} \mathrm{P}<0.05 ;{ }^{\mathrm{d}} \mathrm{P}<0.01 ;{ }^{\mathrm{e}} \mathrm{P}<0.001$. miR, microRNA; TP53, tumor protein 53; MSP, methylation-specific polymerase chain reaction; CRC, colorectal cancer; PIN, polymorphism within intron.
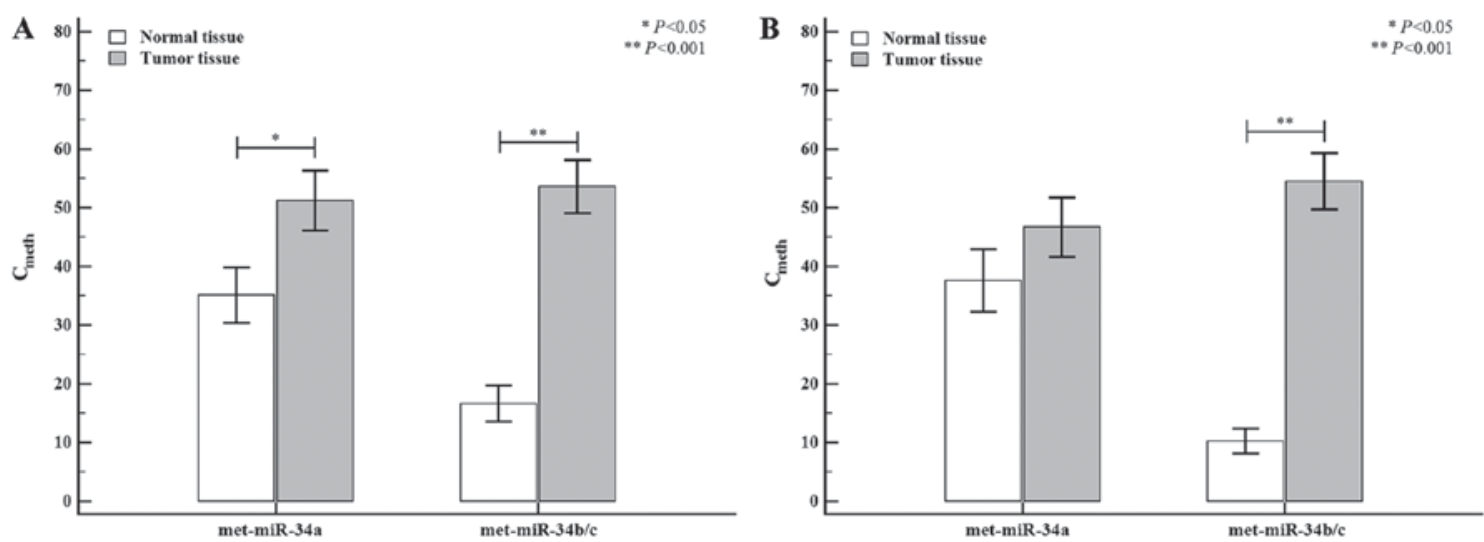

Figure 3. Differential methylation status of miR-34 family between normal and tumor tissues in the colon and rectal region. (A) The methylation status of miR-34 family in the colon. The methylation levels of miR-34a and miR-34b/c were elevated in the colon tumor tissues compared with normal tissues, and the methylation of miR-34b/c was particularly high. (B) The methylation status of miR-34b/c was increased in rectal tumor tissues when compared with normal tissues. Unlike the differences observed in the colon tumors, no differences were found in the miR-34a methylation levels between normal and tumor tissues. ${ }^{*} \mathrm{P}<0.05$ and ${ }^{* *} \mathrm{P}<0.01$, as indicated. miR/miRNA, microRNA; met, methylated.

$\mathrm{P}<0.0001)$ than the corresponding methylation levels observed in rectal tumors (normal tissue: $10.07 \pm 2.23$ vs. tumor tissue: 54.46 $\pm 4.99 ; \mathrm{P}<0.0001)$.

The gene polymorphism of TP53 showed a significant correlation with the methylation of the miR-34a and $-34 \mathrm{~b} / \mathrm{c}$ promoter region in the analysis of the correlation between the polymorphisms and DNA methylation levels (data not shown).
Therefore, we were performed that analysis of variance for the methylation amount of $\mathrm{miR}-34 \mathrm{a}$ and $\mathrm{miR}-34 \mathrm{~b} / \mathrm{c}$, the results of the TP53 and mir-34bc polymorphism frequency analysis are shown in Table II. No statistically significant differences in genotype frequencies were found when the normal and tumor tissues were compared. However, the methylation levels of the miR-34 miRNAs were significantly increased in the tumor 
Table III. TP53 and miR-34b/c genotype frequencies and miR-34 family expression levels between normal and tumor tissue.

\begin{tabular}{|c|c|c|c|c|c|c|c|}
\hline \multirow[b]{2}{*}{ Genotypes } & \multirow[b]{2}{*}{ CRC (n=104) } & \multicolumn{3}{|c|}{ miR-34a } & \multicolumn{3}{|c|}{$\mathrm{miR}-34 \mathrm{~b} / \mathrm{c}$} \\
\hline & & Normal tissue & Tumor tissue & P-value ${ }^{b}$ & Normal tissue & Tumor tissue & P-value \\
\hline \multicolumn{8}{|c|}{ TP53 72 codon } \\
\hline GG & $46(44.2)$ & $1.16 \pm 0.24$ & $1.14 \pm 0.19$ & 0.801 & $0.92 \pm 1.13$ & $0.68 \pm 1.50$ & 0.386 \\
\hline GC & $42(40.4)$ & $1.22 \pm 0.30$ & $1.14 \pm 0.22$ & 0.201 & $1.09 \pm 1.18$ & $0.73 \pm 1.03$ & 0.150 \\
\hline $\mathrm{CC}$ & $16(15.4)$ & $1.19 \pm 0.18$ & $1.19 \pm 0.25$ & 0.992 & $1.64 \pm 1.35$ & $0.14 \pm 0.99$ & $0.001^{\mathrm{d}}$ \\
\hline P-value ${ }^{a}$ & & 0.546 & 0.749 & & 0.117 & 0.259 & \\
\hline \multicolumn{8}{|l|}{ TP53 PIN } \\
\hline A1A1 & $96(92.3)$ & $1.19 \pm 0.27$ & $1.16 \pm 0.22$ & 0.336 & $1.08 \pm 1.22$ & $0.63 \pm 1.29$ & $0.016^{\mathrm{c}}$ \\
\hline A1A2 & $7 \quad(6.7)$ & $1.05 \pm 0.04$ & $1.06 \pm 0.08$ & 0.747 & $1.38 \pm 1.05$ & $0.46 \pm 0.75$ & 0.080 \\
\hline A2A2 & $1(1.0)$ & 1.39 & 1.01 & & 0.94 & -0.62 & \\
\hline P-value ${ }^{a}$ & & 0.258 & 0.394 & & 0.807 & 0.586 & \\
\hline \multicolumn{8}{|l|}{ TP53 MSP } \\
\hline GG & 95 (91.3) & $1.19 \pm 0.26$ & $1.16 \pm 0.22$ & 0.436 & $1.09 \pm 1.22$ & $0.62 \pm 1.29$ & $0.011^{\mathrm{c}}$ \\
\hline AG & $8 \quad(7.7)$ & $1.13 \pm 0.23$ & $1.06 \pm 0.07$ & 0.430 & $1.21 \pm 1.08$ & $0.66 \pm 0.89$ & 0.280 \\
\hline AA & $1(1.0)$ & 1.39 & 1.01 & & 0.94 & -0.62 & \\
\hline P-value ${ }^{a}$ & & 0.594 & 0.345 & & 0.956 & 0.622 & \\
\hline \multicolumn{8}{|l|}{$\mathrm{miR}-34 \mathrm{~b} / \mathrm{c}$} \\
\hline $\mathrm{TT}$ & $55(52.9)$ & $1.19 \pm 0.26$ & $1.18 \pm 0.25$ & 0.883 & $1.24 \pm 1.36$ & $0.74 \pm 0.95$ & $0.032^{\mathrm{c}}$ \\
\hline $\mathrm{TC}$ & $41(39.4)$ & $1.18 \pm 0.26$ & $1.10 \pm 0.15$ & 0.125 & $0.96 \pm 0.95$ & $0.44 \pm 1.66$ & 0.089 \\
\hline $\mathrm{CC}$ & $8(7.7)$ & $1.22 \pm 0.24$ & $1.19 \pm 0.21$ & 0.836 & $0.84 \pm 1.12$ & $0.51 \pm 0.75$ & 0.499 \\
\hline$P$-value ${ }^{a}$ & & 0.948 & 0.241 & & 0.435 & 0.532 & \\
\hline
\end{tabular}

${ }^{\text {a }} \mathrm{P}$-value calculated by one-way analysis of variance test; ${ }^{\mathrm{b}} \mathrm{P}$-value calculated by paired $\mathrm{t}$-test; ${ }^{\mathrm{c}} \mathrm{P}<0.05$; ${ }^{\mathrm{d}} \mathrm{P}<0.001$. miR, microRNA; TP53, tumor protein 53; MSP, methylation-specific polymerase chain reaction; CRC, colorectal cancer; PIN, polymorphism within intron.

tissues compared with normal tissue. The miR-34a methylation levels in the TP53 PIN A1A1 (48.56 \pm 36.49$)$, TP53 MSP

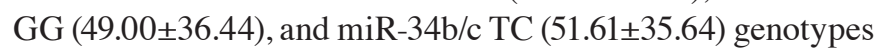
were increased in the tumor tissue compared with normal tissue; however, the methylation levels of the miR-34 miRNAs were not significantly different between the genotypes in each polymorphism. Interestingly, the $\mathrm{miR}-34 \mathrm{~b} / \mathrm{c}$ methylation levels were significantly elevated in tumor tissue compared with normal tissue across all of the polymorphisms, with the miR-34b/c GG genotype (59.64 \pm 31.19 ; $\mathrm{P}<0.001)$ exhibiting the highest degree of methylation (Table II).

We confirmed the expression of miRNAs by genetic polymorphism, unfortunately, we did not find any significant effect on polymorphisms (Table III). However, when the miRNA expression levels analyzed according to haplotype of TP53 polymorphisms, we could confirm difference for the expression of miR-34a and miR-34b/c (Table IV). In particular, the expression pattern of miR-34b/c was increased in TP53 PIN/MSP haplotypes, which were confirmed in both normal and tumor tissues. In addition, this haplotype also confirmed the increased expression of miR-34a in tumor tissues.

\section{Discussion}

CRC is an age-related disease and a multistage process involving both genetic and epigenetic changes (43). Recently, several miRNA profiling studies demonstrated that miRNAs are distinctively and differentially expressed in cancer tissues compared with normal adjacent tissues (44). Hence, epigenetic mechanisms appear to influence the deregulation of miRNAs in cancer pathogenesis (4).

The miR-34 miRNA family is comprised of miR-34a, miR-34b, and miR-34c, which are encoded by two different genes. Although miR-34a is encoded by its own transcript in chr.1p36.23, miR-34b and miR-34c share a common primary transcript in chr.11q23. The members of the miR-34 family are reportedly direct targets of TP53, which induces apoptosis, cell cycle arrest, and senescence, indicating a potential tumor suppressor role of the miR-34 miRNAs $(6,13)$. In particular, miR-34 miRNAs enable TP53 to regulate numerous proteins, despite the prior synthesis of their transcripts (6). As well, several studies have shown that miR-34 miRNAs are silenced by $\mathrm{CpG}$ methylation $(45,46)$.

According to prior in vitro studies, miR-34a overexpression causes the decreased proliferation and activation of apoptosis in multiple tumor cells, indicating that miR-34a could play a role in tumor suppression. In addition, miR-34a is downregulated in several tumor types $(7,17,19,47-49)$. To date, over $77 \mathrm{miR}-34$ targets have been validated, including factors that control the cell cycle (CDK4, CDK6, c-Myc, and E2F3), regulators of apoptosis (BCL2, survivin, and CREB), proteins involved in invasion (c-Met, AXL receptor, and the RAS-oncogene homolog RRAS), factors related to epithelial mesenchymal transition (EMT-inducing transcription factor 
Table IV. Associations between miR-34 family expression levels and the TP53 haplotype in normal and tumor tissues.

\begin{tabular}{|c|c|c|c|c|c|c|}
\hline \multirow[b]{2}{*}{ Allele combination model } & \multicolumn{3}{|c|}{ miR-34a expression } & \multicolumn{3}{|c|}{$\mathrm{miR}-34 \mathrm{~b} / \mathrm{c}$ expression } \\
\hline & Normal tissue & Tumor tissue & P-value ${ }^{b}$ & Normal tissue & Tumor tissue & P-value \\
\hline \multicolumn{7}{|l|}{ TP53 codon 72/PIN/MSP } \\
\hline $\mathrm{G}-\mathrm{A} 1-\mathrm{G}$ & $1.36 \pm 1.88$ & $2.29 \pm 3.42$ & $0.015^{\mathrm{c}}$ & $2.53 \pm 3.62$ & $2.56 \pm 5.35$ & 0.963 \\
\hline G-A1-A & $2.30 \pm 2.24$ & $4.96 \pm 5.34$ & 0.288 & $6.32 \pm 6.84$ & $11.45 \pm 15.95$ & 0.485 \\
\hline C-A1-G & $1.25 \pm 2.13$ & $2.17 \pm 2.94$ & 0.069 & $2.88 \pm 3.60$ & $3.41 \pm 7.10$ & 0.639 \\
\hline C-A2-G & $2.25 \pm 2.50$ & $5.22 \pm 5.93$ & 0.331 & $6.25 \pm 7.64$ & $10.71 \pm 17.71$ & 0.619 \\
\hline P-value & 0.479 & 0.075 & & $0.031^{\mathrm{c}}$ & $0.003^{\mathrm{d}}$ & \\
\hline \multicolumn{7}{|l|}{ TP53 codon 72/PIN } \\
\hline G-A1 & $1.41 \pm 1.90$ & $2.43 \pm 3.56$ & $0.008^{\mathrm{d}}$ & $2.75 \pm 3.93$ & $3.09 \pm 6.64$ & 0.664 \\
\hline C-A1 & $1.25 \pm 2.13$ & $2.17 \pm 2.94$ & 0.069 & $2.88 \pm 3.60$ & $3.41 \pm 7.10$ & 0.639 \\
\hline $\mathrm{C}-\mathrm{A} 2$ & $1.87 \pm 2.14$ & $4.43 \pm 5.02$ & 0.239 & $4.97 \pm 6.61$ & $7.74 \pm 15.33$ & 0.669 \\
\hline P-value ${ }^{a}$ & 0.711 & 0.270 & & 0.362 & 0.269 & \\
\hline \multicolumn{7}{|l|}{ TP53 codon 72/MSP } \\
\hline G-G & $1.36 \pm 1.88$ & $2.29 \pm 3.42$ & $0.015^{\mathrm{c}}$ & $2.53 \pm 3.62$ & $2.56 \pm 5.35$ & 0.963 \\
\hline G-A & $2.30 \pm 2.24$ & $4.96 \pm 5.34$ & 0.288 & $6.32 \pm 6.84$ & $11.45 \pm 15.95$ & 0.485 \\
\hline $\mathrm{C}-\mathrm{G}$ & $1.33 \pm 2.16$ & $2.44 \pm 3.33$ & $0.038^{c}$ & $3.19 \pm 4.13$ & $4.08 \pm 8.57$ & 0.491 \\
\hline P-value ${ }^{a}$ & 0.694 & 0.338 & & 0.124 & $0.024^{c}$ & \\
\hline \multicolumn{7}{|l|}{ TP53 PIN/MSP } \\
\hline A1-G & $1.32 \pm 1.96$ & $2.25 \pm 3.26$ & $0.002^{\mathrm{d}}$ & $2.65 \pm 3.60$ & $2.85 \pm 6.00$ & 0.727 \\
\hline A1-A & $2.30 \pm 2.24$ & $4.96 \pm 5.34$ & 0.288 & $6.32 \pm 6.84$ & $11.45 \pm 15.95$ & 0.485 \\
\hline A2-G & $2.25 \pm 2.50$ & $5.22 \pm 5.93$ & 0.331 & $6.25 \pm 7.64$ & $10.71 \pm 17.71$ & 0.619 \\
\hline P-value ${ }^{a}$ & 0.304 & $0.032^{\mathrm{c}}$ & & $0.013^{\mathrm{c}}$ & $0.001^{\mathrm{e}}$ & \\
\hline
\end{tabular}

${ }^{a} \mathrm{P}$-value calculated by one-way analysis of variance test; ${ }^{\mathrm{b}} \mathrm{P}$-value calculated by paired t-test; ${ }^{\mathrm{C}} \mathrm{P}<0.05 ;{ }^{\mathrm{d}} \mathrm{P}<0.01$; ${ }^{\mathrm{e}} \mathrm{P}<0.001$. miR, microRNA; TP53, tumor protein 53; MSP, methylation-specific polymerase chain reaction; PIN, polymorphism within intron.

SNAIL or the zinc finger 281 protein), proteins involved in the formation of cancer stem cells (Notch1-4, WNT1, WNT3, $\beta$-catenin, and CD44), and factors that regulate metabolism (hexokinase 1 and 2, glucose-6-phosphate isomerase, pyruvate dehydrogenase kinase 1 , and lactate dehydrogenase A) $(50,51)$. Consequently, the diverse roles of members of the miR-34 family may lead to functional abnormalities such as Wnt signaling, EMT, G1-arrest, or cancer cell progression, leading to carcinogenesis (50). To this end, recent reports suggest that aberrant miR-34b/c promoter methylation is significantly correlated with the metastasis of tumor cells to the lymph nodes $(25,49)$. Finally, miR-34b and miR-34c are directly regulated by promoter hypermethylation and p53 in response to DNA damage or oncogenic stress $(14-16,25,52)$. In fact, p53 regulates the expression of miR-34 via p53 binding sites within miR-34a and miR-34b/c promoter regions. Consequently, the antioncogenic action of miR-34 is regulated by $\mathrm{p} 53$.

In a previous study (53), we analyzed the association of SNPs of miR-34b/c and TP53 Arg72Pro with the risk of colon cancer. The previous study presented the association with risk of colon cancer to the TP53 Arg72Pro CC genotype (53), and we considered that this association may be related to the regulation of the miR-34 family expression or methylation in cancer tissues. Therefore, in this study, we showed that the methylation or expression of miR-34 miRNAs and the affected
TP53 polymorphisms differ between colorectal tumors and normal tissues. Specifically, the methylation status of miR-34a and $\mathrm{miR}-34 \mathrm{~b} / \mathrm{c}$ was increased in tumor tissues compared with the normal tissue. As well, we found that miR-34 miRNAs are downregulated in tumor tissues compared with paired normal tissues and that this apparent downregulation is associated with increased methylation of miR-34 miRNAs in colorectal tissues. Furthermore, the haplotypes of TP53 polymorphisms (codon 72-PIN) were shown to influence miR-34b/c expression level in normal and cancer tissues. Interestingly, this is the first report of association with expression and methylation by the SNPs, and this results may be applicated for base data that functional research of CRC. Although it has been established that p53 functions as a tumor suppressor, reports also indicate an emerging role of p53 as an important regulator of metabolic homeostasis, a critical aspect of most major cellular processes $(54,55)$. The roles of p53 are fundamental for cell homeostasis and include metabolic homeostasis, which safeguards against latent cancer, as well as its more classical roles that include genome protection, DNA repair, and programmed cell death (56). Critical mutations in the TP53 gene are common in most cancers and are major contributors to cancer progression. Previous studies have likewise indicated the regulation of the TP53 gene by TP53 haplotypes $(50,51,57)$. In particular, studies have shown that the TP53 haplotype containing the codon 72-PIN polymorphism affected TP53 function through 
the formation of various haplotypes $(50,51)$, and that TP53 polymorphisms were presented to linkage disequilibrium (LD) blocks, which were formed many haplotypes and affect to TP53 abnormality (57). In our previous study, we reported an association between CRC risk and TP53 polymorphisms combination model (53). Furthermore, the TP53 haplotypes containing polymorphisms (e.g., codon 72-PIN) influenced $\mathrm{miR}-34 \mathrm{~b} / \mathrm{c}$ expression levels in normal and cancer tissues, suggesting altered regulation of TP53. Interestingly, this is the first report of an association between SNP expression and methylation; thus, these results may be applicable to and serve as the foundation for future CRC research.

In summary, we determined that the hypermethylation of $\mathrm{miR}-34 \mathrm{a}$ and $\mathrm{miR}-34 \mathrm{~b} / \mathrm{c}$ is a relatively common event in $\mathrm{CRC}$, and that the methylation status affects miR-34 expression. We likewise found that promoter methylation in miR-34 miRNAs and polymorphisms in the TP53 codon 72 are a relatively common event associated with CRC risk. Our study had several limitations. First, all patients were selected from a single institution in Korea and the small sample size could limit the statistical power. Second, further studies are needed to define the relationship between DNA hypermethylation and the pathogenesis of CRC.

\section{Acknowledgements}

Not applicable.

\section{Funding}

This study was partly supported by the National Research Foundation of Korea (NRF) Grant funded by the Korean Government (NRF-2018R1D1A1A09082764 and 2018R1D1A1B07047604) and partly supported by the Korea Health Technology R\&D Project from the Ministry of Health and Welfare, Republic of Korea (grant no. HI18C19990200).

\section{Availability of data and materials}

All data generated or analyzed during this study are included in this published article.

\section{Authors' contributions}

JWK, KK and NKK conceived and designed the experiments. KHL, JOK, HSP, CSR, JYL and DK performed the experiments. HHJ, JOK, HSP, CSR and JYL analyzed the data and performed statistical analyses. HHJ, KK, KHL, DK and NKK contributed reagents/material/analysis tools. HHJ and KK wrote the manuscript. JWK and NKK prepared the references and managed the data. All authors reviewed the manuscript. All authors read and approved the final manuscript.

\section{Ethics approval and consent to participate}

The present study was approved by the Institutional Review Board of CHA Bundang Medical Center (Seongnam, Republic of Korea; IRB no. 2009-08-077-010) and written informed consent was provided by all patients.

\section{Patient consent for publication}

Not applicable.

\section{Competing interests}

The authors declare that they have no competing interests.

\section{References}

1. Roy S, Levi E, Majumdar AP and Sarkar FH: Expression of miR-34 is lost in colon cancer which can be re-expressed by a novel agent CDF. J Hematol Oncol 5: 58, 2012.

2. Lodygin D, Tarasov V, Epanchintsev A, Berking C, Knyazeva T, Körner H, Knyazev P, Diebold J and Hermeking H: Inactivation of miR-34a by aberrant $\mathrm{CpG}$ methylation in multiple types of cancer. Cell Cycle 7: 2591-2600, 2008.

3. The Korea National Statistical Office Report 2015: Change in leading causes of death (2000-2015). Korea National Statistical Office http://kosis.kr/statHtml/statHtml.do? orgId=101\&tblId=DT_1B34E13\&vw_cd=MT_ZTITLE\&list $\mathrm{id}=\mathrm{D} 11 \&$ seqNo=\&lang_mode=ko\&language=kor\&obj_var_id= \&itm_id=\&conn_path=MT_ZTITLE. Accessed January 26, 2018.

4. Bartel DP: MicroRNAs: Genomics, biogenesis, mechanism, and function. Cell 116: 281-297, 2004.

5. Park Y, Lee J, Oh JH, Shin A and Kim J: Dietary patterns and colorectal cancer risk in a Korean population: A case-control study. Medicine (Baltimore) 95: e3759, 2016.

6. Gallardo E, Navarro A, Viñolas N, Marrades RM, Diaz T, Gel B, Quera A, Bandres E, Garcia-Foncillas J, Ramirez J and Monzo M: miR-34a as a prognostic marker of relapse in surgically resected non-small-cell lung cancer. Carcinogenesis 30: 1903-1909, 2009.

7. Tarasov V, Jung P, Verdoodt B, Lodygin D, Epanchintsev A, Menssen A, Meister $\mathrm{G}$ and Hermeking H: Differential regulation of microRNAs by p53 revealed by massively parallel sequencing: miR-34a is a p53 target that induces apoptosis and G1-arrest. Cell Cycle 6: 1586-1593, 2007.

8. Zamore PD and Haley B: Ribo-gnome: The big world of small RNAs. Science 309: 1519-1524, 2005.

9. Hutvágner G, McLachlan J, Pasquinelli AE, Bálint E, Tuschl T and Zamore PD: A cellular function for the RNA-interference enzyme Dicer in the maturation of the let-7 small temporal RNA. Science 293: 834-838, 2001.

10. Lund E, Güttinger S, Calado A, Dahlberg JE and Kutay U: Nuclear export of microRNA precursors. Science 303: 95-98, 2004.

11. Croce CM: Causes and consequences of microRNA dysregulation in cancer. Nat Rev Genet 10: 704-714, 2009.

12. Davalos V and Esteller M: MicroRNAs and cancer epigenetics: A macrorevolution. Curr Opin Oncol 22: 35-45, 2010.

13. Ahmad A, Zhang W, Wu M, Tan S and Zhu T: Tumor-suppressive miRNA-135a inhibits breast cancer cell proliferation by targeting ELK1 and ELK3 oncogenes. Genes Genomics 40: 243-251, 2018.

14. Bommer GT, Gerin I, Feng Y, Kaczorowski AJ, Kuick R, Love RE, Zhai Y, Giordano TJ, Qin ZS, Moore BB, et al: p53-mediated activation of miRNA34 candidate tumor-suppressor genes. Curr Biol 17: 1298-1307, 2007.

15. He L, He X, Lim LP, de Stanchina E, Xuan Z, Liang Y, Xue W, Zender L, Magnus J, Ridzon D, et al: A microRNA component of the p53 tumour suppressor network. Nature 447: 1130-1134, 2007.

16. He X, He L and Hannon GJ: The guardian's little helper: microRNAs in the p53 tumor suppressor network. Cancer Res 67: 11099-11101, 2007.

17. Bagchi A, Papazoglu C, Wu Y, Capurso D, Brodt M, Francis D, Bredel M, Vogel H and Mills AA: CHD5 is a tumor suppressor at human 1p36. Cell 128: 459-475, 2007.

18. Chang TC, Wentzel EA, Kent OA, Ramachandran K, Mullendore M, Lee KH, Feldmann G, Yamakuchi M, Ferlito M, Lowenstein CJ, et al: Transactivation of miR-34a by p53 broadly influences gene expression and promotes apoptosis. Mol Cell 26: 745-752, 2007.

19. Mori N, Morosetti R, Spira S, Lee S, Ben-Yehuda D, Schiller G, Landolfi R, Mizoguchi H and Koeffler HP: Chromosome band $1 p 36$ contains a putative tumor suppressor gene important in the evolution of chronic myelocytic leukemia. Blood 92: 3405-3409, 1998. 
20. Welch C, Chen Y and Stallings RL: MicroRNA-34a functions as a potential tumor suppressor by inducing apoptosis in neuroblastoma cells. Oncogene 26: 5017-5022, 2007.

21. Hrašovec S and Glavač D: MicroRNAs as novel biomarkers in colorectal cancer. Front Genet 3: 180, 2012.

22. Cho SH, Ko JJ, Kim JO, Jeon YJ, Yoo JK, Oh J, Oh D, Kim JW and Kim NK: 3'-UTR polymorphisms in the miRNA machinery genes DROSHA, DICER1, RAN, and XPO5 are associated with colorectal cancer risk in a Korean population. PLoS One 10 $\mathrm{e} 0131125,2015$.

23. Toyota M, Suzuki H, Sasaki Y, Maruyama R,Imai K, Shinomura Y and Tokino T: Epigenetic silencing of microRNA-34b/c and B-cell translocation gene 4 is associated with $\mathrm{CpG}$ island methylation in colorectal cancer. Cancer Res 68: 4123-4132, 2008

24. Kozaki K, Imoto I, Mogi S, Omura K and Inazawa J: Exploration of tumor-suppressive microRNAs silenced by DNA hypermethylation in oral cancer. Cancer Res 68: 2094-2105, 2008.

25. Lujambio A, Calin GA, Villanueva A, Ropero S, Sánchez-Céspedes M, Blanco D, Montuenga LM, Rossi S, Nicoloso MS, Faller WJ, et al: A microRNA DNA methylation signature for human cancer metastasis. Proc Natl Acad Sci USA 105: 13556-13561, 2008.

26. Kong YW, Ferland-McCollough D, Jackson TJ and Bushell M: microRNAs in cancer management. Lancet Ooncol 13: e249-e258, 2012

27. Lujambio A, Ropero S, Ballestar E, Fraga MF, Cerrato C, Setién F, Casado S, Suarez-Gauthier A, Sanchez-Cespedes M, Git A, et al: Genetic unmasking of an epigenetically silenced microRNA in human cancer cells. Cancer Res 67: 1424-1429, 2007.

28. Iwai $\mathrm{N}$ and Naraba H: Polymorphisms in human pre-miRNAs. Biochem Biophys Res Commun 331: 1439-1444, 2005.

29. Xu Y, Liu L, Liu J, Zhang Y, Zhu J, Chen J, Liu S, Liu Z, Shi H, Shen $\mathrm{H}$ and $\mathrm{Hu} \mathrm{Z}$ : A potentially functional polymorphism in the promoter region of $\mathrm{miR}-34 \mathrm{~b} / \mathrm{c}$ is associated with an increased risk for primary hepatocellular carcinoma. Int J Cancer 128 412-417, 2011

30. Gao LB, Li LJ, Pan XM, Li ZH, Liang WB, Bai P, Zhu YH and Zhang L: A genetic variant in the promoter region of $\mathrm{miR}-34 \mathrm{~b} / \mathrm{c}$ is associated with a reduced risk of colorectal cancer. Biol Chem 394: 415-420, 2013.

31. Hiroki E, Suzuki F, Akahira J, Nagase S, Ito K, Sugawara J, Miki Y, Suzuki T, Sasano H and Yaegashi N: MicroRNA-34b functions as a potential tumor suppressor in endometrial serous adenocarcinoma. Int J Cancer 131: E395-E404, 2012.

32. Bensen JT, Tse CK, Nyante SJ, Barnholtz-Sloan JS, Cole SR and Millikan RC: Association of germline microRNA SNPs in pre-miRNA flanking region and breast cancer risk and survival: The carolina breast cancer study. Cancer Causes Control 24 1099-1109, 2013

33. Dumont P, Leu JI, Della Pietra AC III, George DL and Murphy M: The codon 72 polymorphic variants of p53 have markedly different apoptotic potential. Nat Genet 33: 357-365, 2003.

34. Irarrázabal CE, Rojas C, Aracena R, Márquez C and Gil L: Chilean pilot study on the risk of lung cancer associated with codon 72 polymorphism in the gene of protein p53. Toxicol Lett 144: 69-76, 2003

35. Kuroda Y, Tsukino H, Nakao H, Imai H and Katoh T: p53 codon 72 polymorphism and urothelial cancer risk. Cancer Lett 189: $77-83,2003$.

36. Rokni P, Shariatpanahi AM, Sakhinia E and Kerachian MA: BMP3 promoter hypermethylation in plasma-derived cell-free DNA in colorectal cancer patients. Genes Genomics 40: 423-428, 2018.

37. Jones PA and Baylin SB: The epigenomics of cancer. Cell 128: 683-692, 2007.

38. Vogt M, Munding J, Grüner M, Liffers ST, Verdoodt B, Hauk J, Steinstraesser L, Tannapfel A and Hermeking H: Frequent concomitant inactivation of miR-34a and $\mathrm{miR}-34 \mathrm{~b} / \mathrm{c}$ by $\mathrm{CpG}$ methylation in colorectal, pancreatic, mammary, ovarian, urothelial, and renal cell carcinomas and soft tissue sarcomas. Virchows Arch 458: 313-322, 2011.
39. Eads CA, Danenberg KD, Kawakami K, Saltz LB, Blake C, Shibata D, Danenberg PV and Laird PW: MethyLight: A high-throughput assay to measure DNA methylation. Nucleic Acids Res 28: E32, 2000

40. Cottrell S, Jung K, Kristiansen G, Eltze E, Semjonow A, Ittmann M, Hartmann A, Stamey T, Haefliger C and Weiss G: Discovery and validation of 3 novel DNA methylation markers of prostate cancer prognosis. J Urol 177: 1753-1758, 2007.

41. Deng G, Kakar S and Kim YS: MicroRNA-124a and microRNA-34b/c are frequently methylated in all histological types of colorectal cancer and polyps, and in the adjacent normal mucosa. Oncol Lett 2: 175-180, 2011.

42. Livak KJ and Schmittgen TD: Analysis of relative gene expression data using real-time quantitative PCR and the 2(-Delta Delta C(T)) method. Methods 25: 402-408, 2001.

43. Fearon ER: Molecular genetics of colorectal cancer. Annu Rey Pathol 6: 479-507, 2011.

44. Lu J, Getz G, Miska EA, Alvarez-Saavedra E, Lamb J, Peck D, Sweet-Cordero A, Ebert BL, Mak RH, Ferrando AA, et al: MicroRNA expression profiles classify human cancers. Nature 435: 834-838, 2005.

45. Rinaldi A, Poretti G, Kwee I, Zucca E, Catapano CV, Tibiletti MG and Bertoni F: Concomitant MYC and microRNA cluster miR-17-92 (C13orf25) amplification in human mantle cell lymphoma. Leuk Lymphoma 48: 410-412, 2007.

46. Wang Z, Chen Z, Gao Y, Li N, Li B, Tan F, Tan X, Lu N, Sun Y, Sun J, et al: DNA hypermethylation of microRNA-34b/c has prognostic value for stage I non-small cell lung cancer. Cancer Biol Ther 11: 490-496, 2011.

47. Li N, Fu H, Tie Y, Hu Z, Kong W, Wu Y and Zheng X: miR-34a inhibits migration and invasion by down-regulation of c-Met expression in human hepatocellular carcinoma cells. Cancer Lett 275: 44-53, 2009

48. Tazawa $H$, Tsuchiya $N$, Izumiya $M$ and Nakagama $H$ : Tumor-suppressive miR-34a induces senescence-like growth arrest through modulation of the E2F pathway in human colon cancer cells. Proc Natl Acad Sci USA 104: 15472-15477, 2007.

49. Yan D, Zhou X, Chen X, Hu DN, Dong XD, Wang J, Lu F, Tu L and Qu J: MicroRNA-34a inhibits uveal melanoma cell proliferation and migration through downregulation of c-Met. Invest Ophthalmol Vis Sci 50: 1559-1565, 2009.

50. Rokavec M, Li H, Jiang L and Hermeking H: The p53/miR-34 axis in development and disease. J Mol Cell Biol 6: 214-230, 2014.

51. Hermeking H: The miR-34 family in cancer and apoptosis. Cell Death Differ 17: 193-199, 2010.

52. Roman-Gomez J, Agirre X, Jiménez-Velasco A, Arqueros V, Vilas-Zornoza A, Rodriguez-Otero P, Martin-Subero I, Garate L, Cordeu L, San José-Eneriz E, et al: Epigenetic regulation of microRNAs in acute lymphoblastic leukemia. J Clin Oncol 27: 1316-1322, 2009.

53. Oh J, Kim JW, Lee BE, Jang MJ, Chong SY, Park PW, Hwang SG, Oh D and Kim NK: Polymorphisms of the pri-miR-34b/c promoter and TP53 codon 72 are associated with risk of colorectal cancer. Oncol Rep 31: 995-1002, 2014.

54. Itahana $\mathrm{Y}$ and Itahana K: Emerging roles of $\mathrm{p} 53$ family members in glucose metabolism. Int J Mol Sci 19: pii: E776, 2018.

55. Gnanapradeepan K, Basu S, Barnoud T, Budina-Kolomets A, Kung CP and Murphy ME: The p53 tumor suppressor in the control of metabolism and ferroptosis. Front Endocrinol (Lausanne) 9: 124, 2018

56. Vousden KH: Functions of p53 in metabolism and invasion. Biochem Soc Trans 37: 511-517, 2009.

57. Bellini I, Pitto L, Marini MG, Porcu L, Moi P, Garritano S Boldrini L, Rainaldi G, Fontanini G, Chiarugi M, et al: DeltaN133p53 expression levels in relation to haplotypes of the TP53 internal promoter region. Hum Mutat 31: 456-465, 2010. 